\title{
Kepuasan Kerja Mempengaruhi Kinerja Pelayanan Operasi Elektif
}

\author{
Job Satisfaction Affecting Elective Surgery Service Performance \\ Sujianto ${ }^{1}$, Mulyatim Koeswo ${ }^{2}$, Endah Woro $U^{3}$ \\ ${ }^{1}$ RSUD Dr. Iskak Tulungagung \\ ${ }^{2}$ Program Studi Magister Manajemen Rumah Sakit Fakultas Kedokteran Universitas Brawijaya Malang \\ ${ }^{3}$ RSUD Ngudi Waluyo Wlingi Blitar
}

\begin{abstract}
ABSTRAK
Kinerja pelayanan operasi elektif merupakan kontributor penting dalam kinerja dan keuangan rumah sakit. Penelitian ini bertujuan untuk mengetahui hubungan antara kepuasan kerja petugas kamar operasi dengan kinerja pelayanan operasi elektif di RSUD Ngudi Waluyo Wlingi Kabupaten Blitar. Penelitian ini merupakan penelitian kuantitatif menggunakan pendekatan cross sectional dengan uji regresi linierpada 30 petugas kamar operasi di RSUD Ngudi Waluyo Wlingi Kabupaten Blitar. Instrumen penelitian menggunakan kuesioner kepuasan kerja dan kinerja pelayanan operasi elektif. Hasil penelitian menunjukkan bahwa ada hubungan bermakna antara kepuasan kerja terhadap kinerja tunggu pelayanan operasi elektif, sedangkan jenis kelamin, status kepegawaian dan pendidikan tidak menunjukkan hubungan bermakna. Kepuasan yang kurang ada pada perbedaan tarip pelayanan operatif menyebabkan memanjangnya waktu tunggu pelayanan operasi elektif. Kajian dan revisi besaran tarip dan jasa pelayanan dapat menjadi pilihan solusi.
\end{abstract}

Kata Kunci: Kepuasan kerja, kinerja operasi elektif

\section{ABSTRACT}

Elective surgery service performance isan important contributor in the hospital performance and finance. This research aims to determine the relationship between job satisfactions of surgery room personnel and elective surgery service performance in Ngudi Waluyo Hospital Wlingi Blitar. This research is a quantitative study using design of cross sectional with linier regression test to 30 surgery room personnel in Ngudi Waluyo Hospital Wlingi Blitar. The instrument uses a questionnaire study of job satisfaction and service performance elective surgery. The results show that there is a significant relationship between job satisfaction and the performance of elective surgery waiting service, whereas gender, employment status and education show no significant correlation. Less satisfaction exist in the differences of operative care rate that lead to prolonged waiting time on elective surgery services. Review and revision of the amount of tariffs and services may become the preferred solution.

Keywords: Elective surgery performance, job satisfaction

Jurnal Kedokteran Brawijaya, Vol. 28, Suplemen No. 1 2014: Sujianto. RSUD Dr. Iskak Tulungagung, Jl. Dr. Wahidin Sudirohusodo, Kedungwaru Tulungagung66223 Tel.(0355)322609Email:antokdoy165@gmail.com 


\section{PENDAHULUAN}

Rumah sakit dalam memberikan pelayanan kepada masyarakat memiliki peran yang sangat strategis dalam meningkatkan derajat kesehatan masyarakat. Pelayanan yang di berikan kepada masyarakat harus bermutu dan sesuai dengan standar. Keputusan Menteri Kesehatan Nomor 129/Menkes/SK/II/2008 tentang standar pelayanan minimal rumah sakit menyebutkan rumah sakit wajib menjalankan standar pelayanan minimal (SPM) dalam memberikan pelayanan kepada publik. Kualitas pelayanan publik merupakan indikator kinerja. Kriteria kinerja pelayanan publik meliputi responsiveness, responsibility, dan accountability (1). Pengukuran mutu kinerja berdasarkan standar pelayanan minimal rumah sakit (SPM-RS), mengacu pada efisiensi dan efektivitas untuk pencapaian tujuan kinerja yang kompetitif dan diterima oleh masyarakat (2). Menurut Kotler dan Keller dalam Mulyadi menyebutkan kinerja yang baik diukur dari tingkat kepuasan pelanggan internal maupun eksternal atas produk yang dihasilkan, berupa perasaan senang atau kecewa, puas atau tidak puas dan apabila melebihi harapan maka pelanggan sangat puas dengan kinerja yang diterima (3). Pelayanan rumah sakit dianggap baik apabila dapat memberikan pelayanan yang cepat dan tepat, dengan informasi yang jelas serta tidak menunggu lama tanpa kejelasan (4).

Kepuasan pelayanan prima pada pasien di pengaruhi oleh waktu tunggu pelayanan, waktu tunggu yang singkat akan meningkatkan kepuasan (5). Standar pelayanan minimal mendefinisikan waktu tunggu operasi elektif adalah tenggang waktu mulai dokter memutuskan untuk operasi yang terencana sampai dengan operasi mulai dilaksanakan. Standar pelayanan minimal yang ditetapkan waktu tunggu operasi elektif kurang dari dua hari. Panjangnya waktu tunggu operasi elektif sangat berpengaruh terhadap kepuasan pasien dan dapat menurunkan citra rumah sakit. Kepuasan pasien tersebut dari aspek responsiveness, aspek yang lain adalah tangibles, reliability, assurance, accessibility dan empathy (6). Hal ini akhirnya berdampak pada kepuasan petugas.

Pelayanan operasi elektif merupakan bagian dari kinerja pelayanan di instalasi bedah sentral. Kinerja merupakan produktivitas atau output dalam bentuk barang atau jasa. Kinerja adalah hasil kerja atau kinerja seseorang maupun kelompok dengan proses input sebagai masukan dan output sebagai keluarannya (7). Waktu tunggu pelayanan operasi elektif merupakan pencapaian dari sebuah kinerja pelayanan kamar operasi. Tsui et al, menjelaskan bahwa kinerja karyawan dapat diukur dengan kuantitas, kualitas, efisiensi, standar professional, kemampuan, penilaian, ketepatan, pengetahuan, dan kreativitas. Berdasarkan Lewa \& Subowo, indikator dari kinerja karyawan adalah faktor kualitas kerja, kuantitas, pengetahuan, keandalan, dan kerjasama (8).

Kepuasan kerja adalah ungkapan perasaan emosional menyenangkan yang bersifat individu karyawan dari kualitas pekerjaan atau prestasi yang telah dicapai dalam suatu pekerjaan yang telah diselesaikan (9). Indikator kepuasan atau ketidakpuasan kerja karyawan terdiri dari beberapa aspek diantaranya tingkat kehadiran, tingkat kesenangan terhadap pekerjaan, keadilan dalam penerimaan gaji atau jasa, kesukaan terhadap jabatan, tanggung jawab terhadap pekerjaan, motivasi kerja, reaksi terhadap kebijakan organisasi dan perilaku penolakan (10).
Rumah Sakit Umum Daerah (RSUD) Ngudi Waluyo Wlingi Kabupaten Blitar merupakan rumah sakit umum milik Pemerintah Derah Kabupaten Blitar dengan klasifikasi B Non Pendidikan. RSUD Ngudi Waluyo memiliki 200 tempat tidur, pada tahun 2012 BOR (Bed Occupancy Rate) mencapai 78,3\%, memiliki empat kamar operasi dengan dua dokter bedah umum, satu orthopedi, dua spesialis obstetri dan ginekologi (kandungan), satu spesialis mata, satu spesialis telinga hidung tenggorok (THT) dan dua dokter spesialis anastesi. Jumlah rata-rata operasi delapan pasien per hari.

Hasil pencapaian standar pelayanan minimal waktu tunggu pelayanan operasi elektif di RSUD Ngudi Waluyo Wlingi masih dibawah standar yaitu mengalami pemanjangan waktu tunggu lebih dari dua hari (11). Pemanjangan waktu tunggu pelayanan operasi elektif ini merupakan salah satu permasalahan yang harus segera diselesaikan. Apabila permasalahan ini tidak segera diselesaikan dapat berdampak buruk terhadap citra rumah sakit yang disebabkan pasien tidak puas. Responsif dalam pelayanan dapat dilihat dari pelayanan yang cepat dan tepat kepada pasien dengan informasi yang jelas. Apabila rumah sakit membiarkan pasien menunggu lama tanpa alasan yang jelas akan dinilai memiliki kualitas pelayanan yang jelek (4)

Berdasarkan hasil studi Mulyono menunjukkan hubungan siqnifikan antara kepuasan kerja dan supervisi dengan kinerja perawat (12). Kepuasan kerja petugas berpengaruh terhadap kinerja karyawan, antara lain kinerja dalam waktu tunggu pelayanan operasi elektif. Kepuasan kerja dapat diukur berdasarkan lima aspek kepuasan kerja sesuai dengan Job Descriptive Index (JDI) yaitu kualitas supervisi (terkait dengan bantuan teknis dan dukungan sosial); hubungan dengan rekan kerja (berkaitan dengan harmoni sosial dan respek) kesempatan promosi (terkait dengan kesempatan untuk pengembangan lebih jauh); dan pembayaran (yang terkait dengan pembayaran yang memadai dan persepsi keadilan) (8). Jasa pelayanan berasal dari tarif layanan dengan prosentasi yang ditetapkan oleh peraturan direktur. Berkurangnya kinerja dokter dipengaruhi oleh besaran jasa pelayanan yang diterima tidak sebanding dengan yang dikerjakan, biarpun jumlah dokter hanya $10 \%$ dari jumlah karyawan tetapi merasa perannya sangat besar dalam pelayanan di rumah sakit (13).

Studi ini bertujuan untuk mengetahui hubungan antara kepuasan petugas kamar operasi dengan kinerja dokter di RSUD Ngudi Waluyo Wlingi. Analisis dari akar masalah dengan melihat hubungan antara kepuasan petugas kamar operasi dengan waktu tunggu pelayanan operasi elektif. Hal ini merupakan langkah pertama yang harus dilakukan sehingga dapat ditentukan alternatif solusi terbaik untuk menyelesaikan permasalahan waktu tunggu pelayanan operasi elektif.

\section{METODE}

Studi ini merupakan penelitian dengan metode pengumpulan data sekunder, yaitu data histori SDM 20112013 serta data primer dengan menggunakan kuesioner dan melakukan brainstorming kepada responden. Responden adalah petugas kamar operasi RSUD Ngudi Waluyo Wlingi yang terdiri dari dokter, perawat dan non perawat dalam kurun waktu bulan September sampai Oktober 2013. Petugas kamar operasi memberikan informasi tentang penyebab pemanjangan waktu tunggu 
operasi elektif. Sampel diambil dari seluruh petugas kamar operasi sebanyak 30 orang.

Pada penelitian ini variabel bebas adalah kepuasan petugas kamar operasi dan variabel terikat adalah kinerja petugas kamar operasi pelayanan. Instrumen penelitian menggunakan kuesioner dengan skala Likert. Skala Likert digunakan untuk menunjukkan perbedaan tingkat, perbedaan derajat, perbedaan jenjang maupun perbedaan kuantitas. Skala Likert yang digunakan pada instrumen ini adalah sangat tidak setuju, tidak setuju, ragu-ragu, setuju, sangat setuju. Instrumen yang digunakan untuk kepuasan kerja dan kinerja dalam waktu tunggu pelayanan operasi elektif. Kuesioner kepuasan kinerja mengunakan kuesioner penelitian Rubadi (14) dan kuesioner kinerja pelayanan menggunakan konsep yang dikembangkan Asi (15).

Data kuantitatif kinerja secara umum dari kuesioner dianalisis dengan menggunakan SPSS versi 19. Uji regresi linier digunakan untuk menguji hubungan kepuasan kerja dan kinerja dengan tingkat signifikan 0,05 (16).

\section{HASIL}

Jumlah subjek studi ini adalah 30 orang terdiri dari 6 orang dokter, 20 orang perawat dan 4 orang non perawat. Pada variabel kepuasan, hasil rekapitulasi kuesioner dari lima indikator di dapatkan hasil pada indikator gaji atau jasa pelayanan menunjukkan pernyataan tidak setuju dan menyebabkan tidak puas. Empat indikator lain yaitu pengawas dalam membantu pekerjaan, ketertarikan terhadap pekerjaan, hubungan dengan rekan kerja dan kesempatan promosi semua menyatakan setuju atau puas.

Pada variabel kinerja pelayanan operasi elektif dari sembilan indikator ada satu indikator yang menyatakan tidak setuju atau tidak baik yaitu pada indikator kedisplinan. Pada indikator pengetahuan, kesadaran kerja, kepatuhan, kerjasama kemandirian, partisipasi, tanggungjawab, inovasi dan kreativitas, kejujuran, budaya pelayanan dan etika kerja semua menyatakan setuju atau dinilai baik. Hasil perhitungan analisis variabel kepuasan kerja dan kinerja pelayanan operasi elektif masing-masing faktor dijelaskan di Tabel 1 . Hasil uji regresi linier menunjukkan tidak ada hubungan antara variabel kinerja dengan variabel jenis kelamin, umur, pendidikan, masa kerja dan jabatan. Terdapat hubungan signifikan kepuasan kerja kinerja terhadap pelayanan operasi elektif.

Tabel 1. Uji regresi linier hubungan antara kepuasan kerja dan karakteristik responden dengan kinerja pelayanan operasi elektif

\begin{tabular}{|c|c|c|c|c|c|}
\hline & \multicolumn{2}{|c|}{$\begin{array}{c}\text { Unstandardized } \\
\text { Coefficients }\end{array}$} & \multicolumn{2}{|c|}{$\begin{array}{c}\text { Standardized } \\
\text { Coefficients }\end{array}$} & \multirow[b]{2}{*}{ Sig } \\
\hline & B & Std. Error & Beta & $\mathbf{t}$ & \\
\hline (Constant) & 157 & 307 & & ,513 & 613 \\
\hline $\begin{array}{l}\text { Jenis } \\
\text { Kelamin }\end{array}$ & ,043 & 077 & ,038 & ,558 & ,582 \\
\hline Jabatan & - ,126 & ,094 &,- 145 & $-1,341$ & 193 \\
\hline $\begin{array}{l}\text { Status } \\
\text { Kepegawaian }\end{array}$ & ,098 & 139 & ,049 & 706 & ,487 \\
\hline Pendidikan & ,001 & ,042 & ,003 & ,027 & 979 \\
\hline Kepuasan & ,930 & ,070 & 924 & 13,231 & ,0001 \\
\hline
\end{tabular}

\section{DISKUSI}

Hasil penelitian ini menunjukan ada hubungan signifikan kepuasan kerja petugas kamar operasi terhadap kinerja waktu tunggu pelayanan operasi elektif. Variabel kepuasan kerja yang kurang terdapat pada indikator jasa pelayanan. Pelayanan yang bermutu dapat dilihat dari aspek akuntabilitas, transparansi, aspek hukum, keterbukaan dan profesionalitas. Evaluasi kinerja rumah sakit mengacu pada standar pelayanan minimal rumah sakit (17). Waktu tunggu pelayanan operasi elektif merupakan salah satu indikator dalam SPM merupakan penilaian kinerja terhadap target yang telah di tetapkan (17). Pemanjangan waktu tunggu operasi elektif akan berdampak pada kepuasan pasien. Waktu tunggu lama sering menjadi masalah di semua layanan, pasien akan dinilai oleh pelayanannya jelek dan akan berdampak pasien tidak puas (5).

Berdasarkan Kotler dalam Solikhah ada tiga harapan atau tuntutan pasien terhadap mutu pelayanan: 1) terhadap personel pemberi pelayanan meliputi: responsif, kompeten, kesopanan, kredibilitas, sensitivitas; 2) terhadap tempat perawatan meliputi: akses, keamanan, penampilan; 3) terhadap proses pelayanan lebih lanjut dapat dipercaya, komunikatif (18). Petugas sangat berpengaruh dalam menentukan mutu pelayanan. Kebebasan dalam melakukan tindakan yang tepat bertujuan untuk mempercepat kesembuhan pasien. Standar mutu yang baik menurut pasien bertujuan menjamin kepuasan pasien dengan tetap memperhatikan besaran biaya yang efisien dan efektif (5).

Kepuasan kerja merupakan sebuah kondisi perasaan emosional yang menyenangkan dirasakan seseorang atas pekerjaannya, prestasi kerja yang telah dicapai. Kepuasan kerja petugas, akan mempengaruhi kinerja. Hubungan timbal balik berpengaruh pada kinerja yang lebih baik. Imbalan yang sesuai dengan yang dikerjakan, akan menimbulkan kepuasan yang akan mengarah kepada peningkatan kinerja (9).

Pengaruh gaji atau jasa pelayanan yang tidak sesuai dengan yang diharapkan akan mempengaruhi kepuasan petugas kamar operasi, yang mempunyai pengaruh sangat kuat terhadap kinerja seseorang ataupun kelompok. Pernyataan ini sesuai dengan hasil studi dari Nofrinaldi hasil uji korelasi product moment antara semua aspek persepsi dan aspek kinerja pada seluruh karyawan menunjukkan hasil yang signifikan. Pada kelompok dokter secara keseluruhan persepsi terhadap sistem pembagian jasa pelayanan berhubungan dengan kinerja, kecuali pada aspek keadilan (13). Aspek lain yang menyebabkan ketidak puasan pemberi pelayanan terhadap jasa pelayanan yang berdampak pada penolakan: 1) waktu pembayaran jasa pelayanan tidak jelas; 2 ) tidak adanya transparansi dalam mekanisme pembagian dan penetapan indeks; 3) ketidakadilan dan ketidaktahuan akan sistem pembagian karena dokter spesialis belum terlibat dalam perumusan sistem pembagian jasa pelayanan yang telah digunakan sebelumnya (13). Pada studi lain menguatkan bahwa insentif mempengaruhi kinerja dan menjadi faktor yang dapat mempengaruhi keharmonisan dokter. Pengakuan dan penghargaan yang diberikan oleh Eka Hospital terhadap dokter spesialis berupa material yang diatur oleh suatu sistem remunerasi. Sistem remunerasi diterapkan berdasarkan kemitraan, ketrampilan, pengalaman dan jumlah pasie bertujuan untuk membuat dokter spesialis 
agar lebih betah dan fokus memberikan pelayanan kepada pasien Eka Hospital (19).

Kurangnya tenaga keperawatan asisten operator dan asisten anastesi baik dari jumlah maupun keahlian dengan sertifikat akan berdampak pada mutu kinerja maupun jumlah yang dikerjakan. Dampak yang paling berat adalah terhadap tuntutan hukum. Tenaga kesehatan adalah seseorang yang memiliki ilmu pengertahuan dan ketrampilan yang didapat melalui pendidikan maupun pelatihan dibidang kesehatan yang dibuktikan dengan ijazah dan sertifikat (20).

Penerapan dan pelaksanaan standar prosedur operasional (SPO) tentang alur penjadwalan operasi elektif dan SPO waktu pelayanan operasi elektif akan berpengaruh terhadap penerapan waktu tunggu pelayanan operasi elektif. Dokumen SPO merupakan alat untuk mengurangi kesalahan dalam memberikan pelayanan, oleh sebab itu SPO harus sesuai dengan setiap jenis pelayanan. Pelaksanaan yang optimal dan dilakukan pengawasan serat evaluasi untuk mengurangi resiko terhadap pelayanan yang diberikan (21).

Studi yang dilakukan Engko melaporkan hasil bahwa kepuasan kerja memiliki hubungan positif terhadap self esteem dengan nilai koefisiensi jalur $=0,089$ namun tidak signifikan ( $p$-value 0,569). Hasil penelitian tersebut menunjukkan hubungan positif dan signifikan antara kepuasan dan self efficacy (nilai koefisiensi jalur=0,259 $p$ velue $=0,060$ ), dan antara kepuasan kerja dengan kinerja individu (nilai koefisiensi jalur=0,252; $p$-velue 0,026) (22). Hasil penelitian tersebut mendukung hasil studi penelitian ini yaitu adanya hubungan kepuasan kerja petugas kamar operasi dengan kinerja pelayanan operasi elektif.

Upaya menentukan alternatif solusi dalam permasalahan waktu tunggu operasi elektif dengan mempertimbangkan usulan dari petugas yang memberikan pelayanan. Perubahan tarip pelayanan tindakan operatif maupun jasa pelayanan merupakan usulan alternatif solusi yang tepat pada saat ini menurut dokter maupun perawat. Pada studi Septianis menemukan ada kecenderungan merugi pada tarip pelayanan tindakan medis operatif pada pasien Jamkesmas di RSMH periode kuartal I tahun 2009 karena sebagian besar (sekitar $98,6 \%$ ) biaya tindakan tidak sesuai (lebih besar) dengan tarif INA-DRG. Hal ini juga didukung oleh hasil perhitungan terhadap rincian komponen biaya pada tiap jenis pelayanan yang diberikan pada pasien (23).

\section{DAFTAR PUSTAKA}

1. Endarti EW. Standar Pelayanan Minimum dalam Sektor Publik. Jurnal Administrasi Publik. 2006; 3(1): 249.

2. Adawiyah R, Thamrin, dan Djafar L. Evaluasi Pelayanan yang di Berikan oleh Perawat pada Ruang Kelas III Rumah Sakit Umum Daerah Dokter Soedarso. Jurnal IImu-IImu Sosial dan IImu Politik Universitas Tajungpura. 2013; 1(1): 1-10.

3. Ardani W dan Suprapti NWS. Pengaruh Kualitas Layanan Terhadap Kepuasan dan WOM (Studi di RSUD Wangaya Denpasar). E-Jurnal Manajemen Universitas Udayana. 2012; 1(2): 240-254.

4. Mulyadi D, Fadli UM, dan Ningsih FCK. Analisis Manajemen Mutu Pelayanan Kesehatan pada Rumah Sakit Islam Karawang. Jurnal Manajemen. 2013;
Pada studi lain oleh Maharani menyebutkan tarif Pelayanan Jampersal untuk persalinan normal dan persalinan dengan operasi SC yang telah ditetapkan oleh pemerintah lebih rendah dari unit cost dan tarif rumah sakit, berdasarkan temuan tersebut upaya yang harus dilakukan RS adalah meningkatkan efisiensi pelayanan, seperti pengembangan clinical pathway (24).

Studi Nofrinaldi mendapatkan perubahan sistem pembagian jasa pelayanan yang berasal dari tarip layanan telah meningkatkan kinerja dokter secara signifikan terutama pada aspek jumlah pekerjaan dan efektivitas biaya, dan kinerja secara keseluruhan. Persepsi terhadap sistem pembagian jasa pelayanan berhubungan dengan kinerja secara signifikan dan cukup kuat. Korelasi antara persepsi dengan kinerja pada kelompok dokter sangat kuat, sedangkan pada kelompok paramedis kekuatan korelasi antara persepsi dengan kinerja dalam kategori cukup kuat (13).

Pada penelitian ini kinerja tidak ada hubungan dengan jenis kelamin. Hal ini disebabkan kinerja profesi kesehatan tidak membedakan jenis kelamin karena sudah di tanamkan mulai dari masa pendidikan (25). Umur tidak menunjukkan ada hubungan dengan kinerja, karena pada pekerjaan operasi bersifat tim sehingga tidak dipengaruhi usia. Pendidikan tidak ada hubungan dengan kinerja karena peran pada pelayanan tindakan operasi disesuaikan dengan pendidikan dan keahlian. Masa kerja menunjukkan tidak ada hubungan dengan kinerja, pembagian tugas tidak memandang masa kerja tetapi berdasarkan keahliannya. Jabatan menunjukkan tidak ada hubungan dengan kinerja, karena jabatan di kamar operasi sudah ditetapkan tugas dan fungsi secara jelas yang berpedoman dengan profesi karyawan.

Studi ini menunjukkan bahwa salah satu akar masalah pemanjangan waktu tunggu pelayanan operasi elektif di Instalasi Bedah Sentral RSUD Ngudi Waluyo Wlingi Kabupaten Blitar berhubungan signifikan dengan kepuasan kerja petugas kamar operasi. Kepuasan yang kurang adalah pada jasa pelayanan yang diterima yang berasal dari tarip pelayanan. Perbedaan tarip pelayanan operatif menyebabkan tidak meratanya waktu tunggu pelayanan operasi elektif. Hal ini ditunjukkan dengan fakta waktu tunggu operasi pada pasien paviliun yang cenderung lebih pendek dibanding dengan pasien jamkesmas. Kajian dan revisi besaran tarip dan jasa pelayanan dapat menjadi pilihan solusi.

10(3): 1203-1219.

5. Sulistiyorini C, Lestari T, dan Rohmadi. Tinjauan Faktor Penyebab Waktu Tunggu Pendaftaran Pasien Umum Rawat Jalan di Rumah Sakit Umum Daerah Sragen. Jurnal Kesehatan. 2008; 2(1): 56-69.

6. Lestari WP, Sunarto, and Kuntari T. Analisa Faktor Penentu Tingkat Kepuasan Pasien di Rumah Sakit PKU Muhammadiyah Bantul. Jurnal Kedokteran dan Kesehatan Indonesia. 2008; 13-14.

7. Almigo N. Hubungan Antara Kepuasan Kerja dengan Produktivitas Kerja Karyawan. Journal Psyche. 2004; 1(1): 50-56.

8. Kristianto D, Suharnomo, dan Ratnawati I. Pengaruh Kepuasan Kerja terhadap Kinerja Karyawan dengan Komitmen Organisasional sebagai Variabel Intervening. Jurnal Bisnis dan Ekonomi. 2012; 10(1): 1- 
10.

9. Han ST, Nugroho A, Kartika EW, dan Kaihatu TS. Komitmen Afektif dalam Organisasi yang di Pengaruhi Perceived Organizational Support dan Kepuasan Kerja. Jurnal Manajemen dan Kewirausahaan. 2012; 14(2): 107-115.

10. Ruvendi R. Imbalan dan Gaya Kepemimpinan Pengaruhnya terhadap Kepuasan Kerja Karyawan di Balai Besar Industri Hasil Pertanian Bogor. Jurnal Ilmiah Binaniaga. 2005; 1(1): 17-26.

11. Waluyo RN. Laporan Tahunan 2012: RSUD Ngudi Waluyo Wlingi Blitar. Blitar: RSUD Ngudi Waluyo; 2012.

12. Mulyono $\mathrm{MH}$, Hamzah $\mathrm{A}$, and Abdullah AZ. Faktor yang Berpengaruh terhadap Kinerja Perawat di Rumah Sakit Tingkat III Ambon. Jurnal Kesehatan Masyarakat Nasional. 2013; 2(1): 18-26.

13. Nofrinaldi, Meliala A, dan Utarini A. Persepsi dan Pengaruh Sistem Pembagian Jasa Pelayanan terhadap Kinerja Karyawan di Rumah Sakit Jiwa Madani. Jurnal Manajemen Pelayanan Kesehatan. 2006; 9(02): 65-71.

14. Rubadi H. Kepuasan Kerja Karyawan Terhadap Komitmen Organisasi pada PD. BPR Astanajapura Kabupaten Cirebon. [Tesis]. Universitas Komputer Indonesia, Bandung. 2011.

15. Asi SP. Pengaruh Iklim Kerja dan Burnout terhadap Kinerja Perawat RSUD dr. Doris Sylvanus Palangka Raya. Jurnal Aplikasi Manajemen. 2012; 11(3): 515523.

16. Miftahurrahman, Wildan MA, dan Aulia HB. Pengaruh Unsur-Unsur Komunikasi terhadap Produktifitas Kerja Pegawai Negeri Sipil di Dinas Pendidikan Kabupaten Bangkalan. [Skripsi]. Universitas Trunojoyo, Bangkalan. 2013.

17. Kuntjoro T dan Djasri H. Standar Pelayanan Minimal Rumah Sakit sebagai Persyaratan Badan Layanan
Umum dan Sarana Peningkatan Kinerja. Jurnal Manajemen Pelayanan Kesehatan. 2007; 10(1): 03-10.

18. Solikhah. Hubungan Kepuasan Pasien dengan Minat Pasien dalam Pemanfaatan Ulang Pelayanan Pengobatan. Jurnal Manajemen Pelayanan Kesehatan. 2008; 11(4): 192-199.

19. Tjung L, Meliala A, dan Trisnantoro L. Keterlekatan Dokter Spesialis di Eka Hospital BSD City dan Pekan Baru. Jurnal Manajemen Pelayanan Kesehatan. 2012; 15(3): 115-123.

20. Wahyudi S. Tanggung Jawab Rumah Sakit terhadap Kerugian Akibat Kelalaian Tenaga Kesehatan dan Implikasinya. Jurnal Dinamika Hukum. 2011; 11(3): 505-521.

21. Heryono A, Pramono D, dan Utarini A. Lama Waktu Operasi, Luas Daerah Operasi, Banyak Larutan Irigasi dan Jenis Anestesi dengan Komplikasi yang Terjadi Pasca Odontektomi. Jurnal Manajemen Pelayanan Kesehatan. 2012; 15(3): 140-146.

22. Engko C. Pengaruh Kepuasan Kerja terhadap Kinerja Individu dengan Self Esteem dan Self Efficacy sebagai Variabel Intervening. Jurnal Bisnis dan Akuntasi. 2008; 10(1): 1-12.

23. Septianis D, Misnaniarti, dan Alwi M. Perbandingan Biaya Tindakan Operatif terhadap INA-DRG pada Program Jamkesmas di RSUD Dr. Mochammad Hoesin Palembang. Jurnal Manajemen Pelayanan Kesehatan. 2010; 13(3): 133-139.

24. Maharani A. Persiapan Rumah Sakit Swata dalam Menerapkan Tarif Pelayanan Jaminan Persalinan Studi Kasus di Rumah Sakit Khusus lbu dan Anak di Kotamadya Malang. Jurnal Manajemen Pelayanan Kesehatan. 2012; 15(3): 111-114.

25. Hartiti T. Program Orientasi dan Karakteristik dengan Kinerja Perawat Pelaksana di RS Islam Roemani PKU Muhammadiyah Semarang.Prosiding Konferensi Nasional PPNI Jawa Tengah. Ungaran, 6 Mei 2012; hal. 180-188. 